\title{
EFEKTIVITAS INFUSA DAUN JAMBU BIJI (Psidium guajava) SEBAGAI PRESERVATIF ALAMI PADA KARKAS PUYUH
}

\author{
(Effectiveness Of Guava Leaf Infusion (Psidium guajava) As A Natural Preservative \\ In Quail Carcasses)
}

\author{
Marlina, E.T ${ }^{1}$, E. Harlia ${ }^{1}$, Y. A. Hidayati ${ }^{1}$, D. Z. Badruzzaman ${ }^{1}$, W. Juanda ${ }^{1}$, A. Aditya \\ ${ }^{1}$ Laboratorium Mikrobiologi dan Penanganan Limbah Fakultas Peternakan \\ Universitas Padjadjaran Bandung \\ Jl. Raya Bandung Sumedang KM 21 Sumedang 45363 Tlp. (022) 7798241 Fax. (022) 7798212 \\ Penulis Koresponden: eulis.tanti@unpad.ac.id
}

Article Submitted: 08-02-2021

Article Accepted: 12-04-2021

\begin{abstract}
Guava leaves can be used as a natural preservative in quail carcass because they contain antimicrobial compounds such as flavonoid and tannin. This study studied the effect of using guava leaves infusion on quail carcass on the total bacteria, Enterobacteriaceae, and early spoilage. The research used an experimental method with a completely randomized design, 3 treatments of guava leaves infusion concentration, namely $\mathrm{P}_{1}=25 \%, \mathrm{P}_{2}=50 \%$. And $\mathrm{P}_{3}=75 \%$, each treatment was repeated 6 times. The application of infusion to quail carcass was carried out by immersion for 15 minutes. Data were analyzed using ANOVA and Turkey's test. The results showed that the total bacteria and Enterobacteriaceae before immersion were $3.80 \times 10^{7} \mathrm{cfu} / \mathrm{g}$ and $1.90 \times 10^{4} \mathrm{cfu} / \mathrm{g}$, respectively. Soaking quail carcass in guava leaves infusion was able to reduce the total bacteria and Enterobacteriaceae to $72.15 \%$ and $78.50 \%$, respectively. The early spoilage was inversely proportional to the total bacteria and Enterobacteriaceae resulted in longer shelf life.
\end{abstract}

Keywords: guava leaves, quail carcass, total bacteria, Enterobacteriaceae, early spoilage

\section{PENDAHULUAN}

Daging puyuh merupakan bahan pangan yang potensial sebagai sumber protein hewani alternatif. Hal ini karena kandungan gizi yang baik sebagai sumber protein dalam daging puyuh cukup baik, yakni kadar protein $21,1 \%$ dan kadar lemak 7,73\% (Tuleun dan Dashe, 2010). Dengan kandungan gizi yang tinggi menyebabkan daging karkas puyuh mudah terurai oleh bakteri pembusuk. Pembusukan adalah perubahan yang membuat produk pangan menjadi tidak layak untuk dikonsumsi manusia (Huis in't Veld, 1996). Pembusukan pada daging merupakan peristiwa kompleks yang melibatkan aktivitas biologis, fisik, dan kimiawi yang menyebabkan kerusakan produk (Casaburi dkk, 2015). Daging termasuk dalam produk pangan kategori highly perishable karena kandungan gizi yang tinggi pada daging dapat mendukung pertumbuhan mikroba yang tinggi (Dave dan Ghaly, 2011; Erkmen dan Bozoglu, 2016). Meskipun terdapat beberapa factor yang menjadi penyebab pembusukan daging namun mikroba adalah penyebab paling umum dari penurunan kualitas panga nasal ternak. Bakteri pembusuk menguraikan lemak, karbohidrat, dan protein dalam daging yang menimbulkan perubahan rasa yang tidak enak, pembentukan lendir dan perubahan warna sehingga daging tidak 
layak (Ercolini dkk, 2006; Nychas dkk, 2008). Kebusukan pada daging pada umumnya ditandai dengan bau busuk, terbentuknya lendir, perubahan tekstur, warna, dan rasa (Adam dan Moss, 2008).

Saat daging merupakan jaringan ternak hidup masih dalam keadaan steril. Daging mulai terkontaminasi setelah perlakuan pasca penyembelihan (Erkmen dan Bozoglu, 2016). Beberapa bakteri pembusuk yang terdapat pada daging adalah Pseudomonas spp., Staphylococcus spp., Streptococcus spp., dan bakteri kelompok Enterobacteriaceae (Stellato dkk., 2016). Pada umumnya kehadiran bakteri pembusuk pada daging terjadi karena adanya kontaminasi silang selama penanganan daging, baik sebelum maupun setelah pengolahan. Jumlah total bakteri pada daging segar berkisar antara $10^{2}-10^{5}$ CFU/cm² (Nychas dkk., 1988; Bell, 1997). Jumlah total bakteri yang tinggi pada daging menyebabkan proses pembusukan semakin cepat (Luong dkk, 2020). Oleh karena itu diperlukan penanganan daging yang baik sebelum pengolahan.

Masalah utama dalam higiene pangan adalah kontaminasi feses pada daging sapi dan daging ayam dengan Enterobacteriaceae seperti jenis Salmonella spp., Escherichia coli, Proteus, dan Klebsiella (Zhao dan deVillenaetal, 2001; Paterson, 2006). Bakteri Enterobacteriaceae biasa ditemukan mengkontaminasi produk daging pasca penyembelihan. Namun demikian, seringkali pada pangan yang sudah dimasak terdeteksi bakteri Enterobacteriaceae. Beberapa bakteri Enterobacteriaceae bersifat patogen, di antaranya anggota genus Enterobacter, Serratia, Escherichia, Proteus, Salmonella, Shigella, dan Klebsiella (Downes dan Ito, 2000).

Bakteri yang biasa ditemukan mengkontaminasi makanan dan minuman, baik yang telah dimasak, dibekukan, maupun yang tidak dimasak dan tidak dibekukan (Stiles dan Ng, 1981) Riga et al.
(2015) menemukan adanya bakteri anggota famili Enterobacteriaceae seperti anggota genus Enterobacter dan Serratia pada makanan dan peralatan makan di salah satu rumah sakit. Menurut Dwiyitno (2010), anggota bakteri anggota famili Enterobacteriaceae seperti anggota genus Salmonella, Shigella, Escherichia juga dapat mengkontaminasi produk perikanan.

Salah satu bahan yang dapat menahan laju kerusakan daging adalah bahan yang mengandung senyawa antibakteri asal tumbuhan. Beberapa tumbuhan secara alamiah mengandung beberapa senyawa antimikroba seperti tannin, quinones, terfenoid, fenol, asam fenolat, flavonoid, alkaloid (Cowan, 1999), kandungan senyawa antimikroba dalam daun jambu biji (Psidium guajava) adalah tanin mencapai 9-12\% (Oktiarni, 2012; Shinde dkk., 2016). Tanin adalah polifenol yang larut dalam mempunyai kemampuan dalam mengendapkan protein seperti gelatin. Tanin biasa ditemukan pada banyak spesies tumbuhan tingkat tinggi dan terakumulasi dalam jumlah sangat besar pada bagian kayu, kulit kayu, daun, buah, dan akar (Scalbert, 1991; Maisetta dkk., 2019). Mekanisme tannin dalam menghambat pertumbuhan bakteri adalah melalui inaktivasi enzim dan materi genetic, dan mengganggu transport protein pada lapisan sel (Cowan, 1999). Jambu biji atau jambu batu adalah tanaman yang banyak ditemui di Indonesia. Pada penelitian ini kandungan antibakteri pada daun jambu biji dapat dimanfaatkan sebagai preservative pada karkas puyuh sehingga dapat menjaga kualitas dagingnya sebelum dilakukan pengolahan lebih lanjut

\section{METODE PENELITIAN}

\section{Persiapan Karkas Puyuh.}

Karkas puyuh diperoleh dari ternak puyuh afkir dengan bobot karkas antara 9598 gram/ekor. Karkas dibersihkan, kemudian digantung untuk mengurangi kadar air pada karkas puyuh. Perlakuan pencelupan pada larutan infusa daun jambu 
biji dilakukan dengan melakukan perendaman selama 15 menit.

\section{Persiapan Infundasi Daun Jambu Biji.}

Daun jambu yang sudah cukup tua dibersihkan menggunakan air bersih kemudian dikeringkan dengan oven suhu $50^{\circ} \mathrm{C}$ selama 2 jam sampai mencapai bahan kering $85 \%$, kemudian diblender sampai menjadi serbuk. Serbuk daun jambu biji dilarutkan dalam aquadest. Infusa diperoleh dengan cara menyaring larutan menggunakan kertas saring agar bahan organic terpisah dengan senyawa aktif sebagai antibakteri (Monisa dkk., 2016).

Persiapan Media Nutrient Agar dan Violet Red Bile Glucose Agar (VRBGA).

Media Nutrient Agar (NA) oxoid 28 $\mathrm{g}$ dilarutkan dalam $1000 \mathrm{ml}$ aquadest, kemudian disterilisasi menggunakan autoclave dengan suhu $121^{\circ} \mathrm{C}$ pada tekanan 1 atm selama 15 menit. Media VRBGA dibuat dengan mensuspensikan 38,5 g media VRGBA instant dalam $1000 \mathrm{ml}$ aquadest, kemudian disterilkan pada suhu $121^{\circ} \mathrm{C}$ tekanan 1 atm selama 15 menit menggunakan autoclave.

\section{Penghitungan Jumlah Total Bakteri dan Enterobacteriaceae}

Penghitungan jumlah total bakteri pada karkas puyuh dilakukan denga mengambil sampel daging puyuh pada setiap bagian karkas (dada, paha, punggung). Metode penghitungan dengan metode pengenceran pada $\mathrm{NaCl}$ fisiologis $0,9 \%$ dan diinkubasikan pada media NA selama 24 jam pada suhu $37^{\circ} \mathrm{C}$. Hasilnya dihitung setiap koloni yang tumbuh pada media agar sebagai jumlah bakteri total (CFU/ml). Penghitungan dilakukan pada karkas sebelum dan sesudah direndam dalam larutan infusa daun jambu biji. Metode yang sama dilakukan untuk menghitung Enterobacteriaceae dengan menggunakan media VRBGA.

\section{Pemeriksaan Awal Pembusukan Daging.}

Uji awal pembusukan daging dilakukan menggunakan uji $\mathrm{H}_{2} \mathrm{~S}$. Pembentukan $\mathrm{H}_{2} \mathrm{~S}$ akibat bakteri yang menginvasi daging. $\mathrm{H}_{2} \mathrm{~S}$ yang dilepaskan pada daging yang membusuk akan diikat dengan $\mathrm{Pb}$ acetat menjadi $\mathrm{PbSO}_{3}$. Daging ditempatkan pada cawan petri yang ditutup dengan kertas saring yang sudah ditetesi dengan $\mathrm{Pb}$ acetat $10 \%$. Pembentukan $\mathrm{H}_{2} \mathrm{~S}$ dapat diamati dengan melihat perubahan warna pada kertas saring berupa bercak hitam.

\section{Analisis Statistik.}

Data yang diperoleh dihitung menggunakan Anova dan Uji Tukey menggunakan program SPSS versi 23 (IBM, 2016).

\section{HASIL DAN PEMBAHASAN}

Rataan jumlah total bakteri pada karkas puyuh sebelum perendaman berkisar antara $1,8 \times 10^{6} \mathrm{CFU} /$ gram. Setelah perendaman menggunakan larutan infusa daun jambu biji terjadi penurunan yang bervariasi antar perlakuan (Tabel 1).

Tabel 1. Penurunan jumlah total bakteri dan Enterobacteriaceae serta awal pembusukan pada karkas puyuh setelah perendaman dengan berbagai konsentrasi infusa daun jambu biji

\begin{tabular}{lccc}
\hline \multirow{2}{*}{ Perlakuan } & \multicolumn{2}{c}{ Penurunan $(\%)$} & \multirow{2}{*}{$\begin{array}{c}\text { Awal kebusukan } \\
\text { (menit) }\end{array}$} \\
\cline { 2 - 3 } & Total Bakteri & Enterobacteriaceae & \\
\hline Infusa daun jambu biji $25 \%$ & $\left.10,05 \pm 5,66^{\mathrm{al}}\right)$ & $12,16 \pm 5,90^{\mathrm{a}}$ & $558,7^{\mathrm{a}}$ \\
Infusa daun jambu biji 50\% & $33,06 \pm 12,78^{\mathrm{b}}$ & $20,15 \pm 9,40^{\mathrm{b}}$ & $610,3^{\mathrm{a}}$ \\
Infusa daun jambu biji 75\% & $42,21 \pm 10,47^{\mathrm{b}}$ & $54,50 \pm 10,18^{\mathrm{c}}$ & $824,8^{\mathrm{b}}$ \\
Air steril (kontrol) & $9,15 \pm 4,42$ & $10,05 \pm 4,12$ & 486,2 \\
\hline
\end{tabular}

Keterangan : ${ }^{1)}$ Huruf yang berbeda ke arah baris menyatakan signifikansi $(\mathrm{P}<0,05)$ 
Jumlah total bakteri pada produk pangan menggambarkan kualitas pangan sehingga layak dikonsumsi oleh konsumen. Kualitas mikroba pada karkas puyuh akan berpengaruh terhadap daya awetnya. Keberadaan senyawa antibakteri pada infusa daun jambu biji berpengaruh terhadap penurunan jumlah total bakteri dan Enterobacteriaceae (Tabel 1). Total bakteri menggambarkan bakteri secara umum, baik bakteri pembusuk maupun pathogen, sedangkan bakteri Enterobacteriaceae menggambarkan lebih spesifik kontaminasi bakteri pathogen. Rataan jumlah total bakteri awal pada karkas puyuh pasca pemotongan adalah $1,8 \times 10^{6} \mathrm{cfu} / \mathrm{gram}$, sedangkan rataan jumlah bakteri Enterobacteriaceae $1,90 \times 10^{4} \mathrm{cfu} / \mathrm{gram}$. Angka ini lebih tinggi dari batas maksimum cemaran mikroba menurut SNI (2009) yakni $1 \times 10^{6} \mathrm{cfu} / \mathrm{gram}$, coliform $1 \times 10^{2} \mathrm{cfu} / \mathrm{gram}$, Escherichia coli $1 \times 10^{1} \mathrm{cfu} / \mathrm{gram}, S$. aureus $1 \times 10^{2} \mathrm{cfu} / \mathrm{gram}$. Banyak factor yang menyebabkan tingginya kontaminasi mikroba pada produk daging, diantaranya adalah sanitasi yang tidak baik pada saat menangani karkas (Hajrawati, 2016; Rouger, 2017; Afshari dkk., 2018). Karkas puyuh diperoleh dari pedagang puyuh afkir dengan pemotongan dilakukan secara tradisional dan tidak dilakukan di rumah potong ayam (RPA).

Hasil penelitian menunjukkan bahwa perendaman menggunakan infusa daun jambu biji sampai $75 \%$ menghasilkan penurunan jumlah total bakteri dan Enterobacteriaceae paling tinggi, yaitu masing 42,21\% dan 54,50 \%. Sebagai kontrol, karkas puyuh yang direndam pada air steril penurunan jumlah total bakteri dan Enterobacteriaceae masing-masing mencapai $9,15 \%$ dan $10,05 \%$ (Tabel 1). Hal ini menggambarkan bahwa senyawa antibakteri yang terkandung dalam infusa daun jambu biji mampu berfungsi sebagai bakterisidal sehingga jumlah bakteri pada karkas puyuh berkurang. Bakterisidal adalah senyawa kimia yang mempunyai aktivitas membunuh bakteri (Silva dkk., 2011; Nemeth dkk, 2015). Beberapa senyawa antibakteri pada infusa daun jambu biji adalah tanin, flavonoid, triterfenoid, saponin, steroid, dan alkaloid (Arya dkk., 2012). Mekanisme aktivitas tanin sebagai antibakteri adalah melalui cara menginaktifkan adhesin sel bakteri, menginaktifkan enzim, dan menganggu transport protein pada lapisan sel (Cowan, 1999). Mekanisme aktivitas flavonoid sebagai antibakteri dibagi menjadi 3 yaitu menghambat sintesis asam nukleat, menghambat fungsi membran sel dan menghambat metabolisme energi (Hendra dkk., 2011). Mekanisme saponin sebagai antibakteri adalah menurunkan tegangan permukaan dinding sel bakteri dan merusak permebialitas membrane (Arabski dkk., 2012), sedangkan mekanisme steroid sebagai antibakteri merusak membrane lipid pada membrane sel (Madduluri dkk., 2013). Mekanisme aktivitas antibakteri alkaloid melalui merusak komponen penyusun peptidoglikan sel bakteri sehingga lapisan tersebut tidak terbentuk secara sempurna yang menyebabkan kematian bakteri (Raji dkk., 2019).

Konsentrasi infusa daun jambu biji mempengaruhi kekuatan daya hambat terhadap total bakteri dan Enterobacteriaceae maupun terhadap umur simpan karkas puyuh sebelum diolah. Semakin tinggi konsentrasi infusa daun jambu biji menghasilkan penurunan bakteri yang semakin tinggi pula. Hal ini berpengaruh secara langsung terhadap daya awet karkas yang digambarkan dengan lamanya waktu awal kebusukan (Tabel 1). Awal kebusukan pada karkas puyuh yang direndam pada infusa daun jambu biji konsentrasi $75 \%$ mencapai 824,8 menit, sedangkan pada konsentrasi $25 \%$ mencapai 558,7 menit dan pada kontrol dengan menggunakan air steril pada menit ke 486,2 sudah muncul tanda awal kebusukan dengan munculnya bintik hitam pada kertas saring. 
periode Umur simpan daging adalah dimungkinkan dan daging dapat dipertahankan karakteristik kualitatifnya sampai terjadinya tanda kebusukan (Lulietto dkk., 2016). Masa simpan daging terkait erat dengan kerusakannya, yang berkorelasi juga dengan konsentrasi bakteri kontaminan yang dapat diterima dan yang tidak dapat diterima, yang akan menimbulkan bau tak sedap, rasa tidak enak dan penampilan yang tidak diinginkan. Hal ini berkaitan dengan jumlah dan jenis mikroorganisme awal ada dan pengaruh lingkungan pertumbuhan selanjutnya. Pada produk daging, total bakteri awal untuk memulai terjadinya pembusukan sekitar $10^{2}-10^{3} \mathrm{cfu} /$ gram, terdiri dari berbagai macam spesies (Ray dan Bhunia, 2013). Daging dikatakan busuk jika dianggap sudah tidak layak untuk dikonsumsi karena perubahan fisik dan kimiawi yang mengubah karakteristik indranya. Salah satu senyawa kimia yang menandakan terjadinya pembusukan pada daging adalah $\mathrm{H}_{2} \mathrm{~S}$. Bakteri anaerob melalui dekomposisi protein dan asam amino akan menghasilkan indole, metilamin, dan $\mathrm{H}_{2} \mathrm{~S}$, sedangkan bakteri aerob menimbulkan lendir, perubahan warna daging, perubahan pada lemak, fosforesen, dan juga menimbulkan bau pada daging (Lulietto dkk., 2016).

\section{KESIMPULAN}

Infusa daun jambu biji (Psidium guajava) dapat meningkatkan umur simpan karkas puyuh sebelum diolah lebih lanjut dengan konsentrasi infusa terbaik $75 \%$. Penurunan jumlah total bakteri dan Enterobacteriaceae menandakan adanya aktivitas antibakteri yang cukup baik pada infusa daun jambu biji.

\section{DAFTAR PUSTAKA}

Adam, M., M.O. Moss., P. McClure. 2015. Food Microbiology. The microbiology of food preservation. $4^{\text {th }}$ Eds. eISBN: 978-1-78262-762-3.
Afshari, A., Baratpour, A. , Khanzade, S. , Jamshidi, A. 2018. Salmonella enteritidis and Salmonella Typhimurium identification in poultry carcasses. Iran J. Microbiol. 10(1):4550 .

Arabski, M., A. Wegierek-Ciuk, G. Czerwonka, A. Lankoff, dan W. Kaca. 2012. Effects of saponins against clinical E. coli strains and eukaryotic cell line. Journal of Biomedicine and Biotechnology, vo. 2012, Article ID 286216, 1-6.

Arya, V., N. Thakur, dan C.P. Kashyap. 2012. Preliminary Phytochemical Analysis of the Extracts of Psidium Leaves. Journal of Pharmacognosy and Phytochemistry. 1(1): 2278-4136.

Bell, R.G., 1997. Distribution and sources of microbial contamination on beef carcasses. J. Appl. Microbiol. 82 (3), 292-300.

Casaburi, A., Piombino, P., Nychas, G.J., Villani, F., Ercolini, D., 2015. Bacterial populations and the volatilome associated to meat spoilage. Food Microbiol. 45, 83-102.

Cowan, M.M. 1999. Plant Products as Antimicrobial Agents. Clinical Microbiology Reviews. P. 564-582. American Society for Microbiology.

Dave, D., Ghaly, A.E., 2011. Meat spoilage mechanisms and preservation techniques: a critical review. Am. J. Agric. Biol. Sci. 6 (4), 486-510.

Darsana, I., I. Besung, H. Mahatmi. 2012. Potensi Daun Binahong (Anredera Cordifolia (Tenore) Steenis) dalam Menghambat Pertumbuhan Bakteri Escherichia coli secara In Vitro. Indonesia Medicus Veterinus. 
Downes F.P dan K. Ito. 2000. Compendium of Methods for the Microbiological

Examination of Foods. $4^{\text {th }}$ Eds., American Public Health Association.

Erkmen, O., Bozoglu, T.F., 2016. Spoilage of meat and meat products. In: Erkmen, O., Bozoglu, T.F. (Eds.), Food Microbiology: Principles into Practice. John Wiley \& Sons. http://dx.doi.org/10.1002/ 9781119237860.ch16.

Ercolini, D., Russo, F., Torrieri, E., Masi, P., Villani, F., 2006. Changes in the spoilage-related microbiota of beef during refrigerated storage under different packaging conditions. Appl. Environ. Microbiol. 72 (7), 4663-4671.

Hajrawati, Fadhilah, M., Wahyuni, dan W. Arief, I.I. 2016. Kualitas Fisik, Mikrobiologis, dan Organoleptik Daging Ayam Broiler pada Pasar Tradisional di Bogor. J. Ilmu Produksi dan Teknologi Hasil Peternakan. 04(03):386- 389.

Hendra R, S. Ahmad, A. Sukari, M.Y. Shukor, E. Oskoueian. 2011. Flavonoid analyses and antimicrobial activity of various parts of Phaleria macrocarpa (Scheff.) Boerl fruit. Int J Mol 12: 3422-3431.

Huis in't Veld, J.H., 1996. Microbial and biochemical spoilage of foods: an overview. Int. J. Food Microbiol. 3 (1), 1118.

Lulietto, M.F., P. Sechi, E. Borgogni, dan B.T. Cenci-Goga. 2016. Meat Spoilage: A critical review of a neglected alteration due to ropy slimeproducing bacteria. Italian Journal of Animal Science. 14 issue $3: 316-326$.
Luong, N.M., L. Coroller, M. Zagorec, JM. Membre, S. Guillou. Spoilage of chilled fresh meat products during storage: A quantitative analysis of literature data. Microorganisms 8(8), 1198;

https://doi.org/10.3390/microorganism $\underline{\text { s8081198. }}$.

Maisetta, G., G. Batoni, P. Caboni, S. Esin, A.C Rinaldi, and P. Zucca. 2019. Tannin profile, antioxidant properties, and antimicrobial activity of extracts from two Mediterranean species of parasitic plant, Cytinus. Complementary and Alternative Medicine. 19(82) 1-11.

Madduluri S, K.B. Rao, B. Sitaram. 2013. In vitro evaluation of the antibacterial activity of five indigenous plant extract against five bacterial pathogens of humans. Pharmacy and pharmaceutical sciences. 5(4): 679-684.

Monisa, F.S., M. Bintang, M. Safithri, S. Falah. 2016. Potensi Ekstrak Tanin Daun dan Kulit Batang Surian sebagai Penghambat Glukosida. Jurnal Ilmu dan Teknologi Kayu Tropis. 14(2): 19.

Nemeth, J., G. Oesch, S. P. Kuster. 2015. Bacteriostatic versus bactericidal antibiotics for patients with serious bacterial infections: systematic review and meta-analysis. Journal of Antimicrobial Chemotherapy, 70(issue 2): 382-395.

Nychas, G.J., Dillon, V., Board, R.G., 1988. Glucose, the key substrate in the microbiological changes occurring in meat and certain meat products. Biotechnol. Appl. Biochem. 10 (3), 203-231. 
Nychas, G.J.E., Skandamis, P.N., Tassou, C.C., Koutsoumanis, K.P., 2008. Meat spoilage during distribution. Meat Sci. 78 (112), 77-89.

Oktiarni, D., S. Manaf, Suripno. 2012. Pengjian Ekstrak Daun Jambu Biji (Psidium guajava Linn.) terhadap Penyembuhan Luka Bakar pada Mencit (Mus musculus). http://repository.unib.ac.id/ :2

Paterson, D.L. 2006. Resistance in Gramnegative bacteria: Enterobacteriaceae. The American Journal of Medicine, 119 (6) supplement 1 : S20-S28.

Raji, P., A.V. Samrot, D. Keerthana, dan S. Karishma. 2019. Antibacterial activity of alkaloids, flavonoids, saponins and tannins mediated green synthesized silver nanoparticles against Pseudomonas aeruginosa and Bacillus subtilis. Journal of Cluster Science, 30: 881-895.

Ray, B. dan A. Bhunia. 2013. Fundamental food microbiology, 5th ed. CRC Press, Boca Raton, FL, USA.

Rouger, A., Tresse, O. dan Zagorec, M. 2017. Bacterial Contaminants of Poultry Meat: Sources, Species, and Dynamics. Microorganisms 5(50):1-16.

Stellato, G., La Storia, A., De Filippis, F., 2016. Overlap of spoilage microbiota between meat and meat processing environment in small-scale vs large- scale retail distribution. Appl. Environ. Microbiol. AEM- 00793.

Shinde, S., A. Deshmukh, A. Deshmukh. 2016. Extraction of Tannin from Psidium guajava leaves. International Journal of Chemical Separation Technology. 2(1): 121-128.

Scalbert, A. 1991. Antimicrobial Properties of Tannins. Review Article Number 63. Phytochemistry 30(12): 38753883.

Silva, F., O. Lourenco, J. A. Queiroz, F.C. Domingues. 2011. Bacteriostatic versus bactericidal activity of ciprofloxacin in Escherichia coli assessed by flow cytometry using a novel far-red dye. The Journal of Antibiotics 64 : 321-325.

Tuleun, C.D and N.A. Dashe. 2010. Effect of dietary levels of toasted mucuna seed meal (tmsm) on the performance and egg quality parameters of laying Javanese quails (Coturnix-Coturnix japonica). Int J Poult Sci. 9(12):10921096.

Zhao,C.B.Ge, J.deVillenaetal. 2001. Prevalence of Campylobacter spp., Escherichia coli, and Salmonella serovars in retail chicken, turkey, pork, and beef from the Greater Washington, D.C., area, Applied and Environmental Microbiology, 67(12): 5431-5436. 